\title{
Enslaved in Dzungaria: what an eighteenth-century crocheting instructor can teach us about overland globalisation
}

\author{
Lisa Hellman (1) \\ Bonn Centre for Dependency and Slavery Studies, University of Bonn, Adenauerallee 18-22, 53113 Bonn, Germany \\ Corresponding author. E-mails: lhellman@uni-bonn.de, lisa.k.hellman@gmail.com
}

\begin{abstract}
This global microhistorical analysis of the Swede Brigitta Scherzenfeldt's capture in Russia and her subsequent enslavement in the Dzungar khanate stresses actors and regions needed to nuance the history of globalisation. The early globalisation process is commonly exemplified with maritime contacts, involving free and often male West European actors. In contrast, this study combines multilingual source material to trace and discuss economic integration, cross-border trade, forced migration, the circulation of knowledge, literary depictions, and diplomatic contacts in the Central Asian borderlands between China and Russia. In the process, I clarify the importance of female, coerced actors, and overland connections between nonEuropean empires for the history of early modern globalisation.
\end{abstract}

Keywords: Central Asia; early modern; gender; globalisation; microhistory; prisoners of war

On 29 June 1709, the Swede Brigitta Scherzenfeldt saw her compatriots defeated by Russian forces at the battle of Poltava. This battle spelled the beginning of the end of the Swedish Baltic Empire, and forced tens of thousands of men and women into captivity. Brigitta was one of them. She was taken prisoner of war, and moved across the steppe as part of the Russian expansion. Seven years later, she was captured anew. Brigitta now became a slave in the Dzungar Empire, where she stayed for nearly two decades, working as a crocheting instructor at the court in Ghulja. Her story spans almost the width of Eurasia, going from western and northern Europe into Russia, Dzungaria, and the Qing Empire; this crocheting instructor shows the impact of several factors currently underestimated in narratives of early globalisation, namely overland connections, non-European empires, and coerced and female actors.

During the early modern era, the eighteenth century especially, interregional contacts became more direct and frequent and had a stronger impact. ${ }^{1}$ Scholarship on global history for this period has produced excellent studies on trade diasporas, imperial endeavours, and migration flows. However, when taken together, these studies may inadvertently lead to a maritime bias; the connections most commonly followed take place overseas, and the typical representative is a European actor intentionally travelling overseas. ${ }^{2}$ This is not to say that there is anything wrong with such studies - I have even written one such book myself. Nevertheless, despite the attention it

${ }^{1}$ C. A. Bayly, The Birth of the Modern World, 1780-1914: Global Connections and Comparisons (Oxford: Blackwell, 2004), $5-12$.

${ }^{2}$ Note the examples of regions and actors put forth in Sven Beckert and Dominic Sachsenmaier, Global History, Globally: Research and Practice around the World (London: Bloomsbury, 2018); for a summary, see Miguel Bandeira Jerónimo, 'Imperial Globalisations', in Explorations in History and Globalization, ed. Cátia Antunes and Karwan Fatah-Black (London: Routledge, 2016), 212-30.

(c) The Author(s), 2021. Published by Cambridge University Press. This is an Open Access article, distributed under the terms of the Creative Commons Attribution licence (http://creativecommons.org/licenses/by/4.0/), which permits unrestricted re-use, distribution and reproduction, provided the original article is properly cited. 
pays to local dominance, subversions, and ambitions, this approach risks framing maritime and European powers as the most active driving forces in the process of globalisation.

The story of Brigitta's life does not only interweave multiple imperial historiographies, it is a global history response to perennial demands that scholars pay more attention to the impact of the borderlands. The grand old man of global history, Andre Gunder Frank, said thirty years ago that 'connections in and through Central Asia are essential for the reconstruction and understanding of the history of all Afro-Eurasia and of each of its never separate parts'. ${ }^{3}$ As this article will demonstrate, we can use the vibrant research from Central Asian studies, not limited to that on the Silk Road, together with scholarship on Qing and Russian history to balance this maritime bias. ${ }^{4}$

In the early eighteenth century, Central Asia was a hornet's nest of competing claims by small groups and vast empires alike. Although the reign of Peter I is commonly seen as an era of Russia 'looking west', Russia was gazing quite as intently to the east. ${ }^{5}$ The borderlands of Central Asia were equally important to China ${ }^{6}$ - this same period saw a dramatic Qing expansion inland; from the beginning of the dynasty, the Qing Empire more than doubled its territory. Just as Russia expanded eastwards, China expanded westwards - and a number of polities were caught in between, including the city states of the Timur basin, and nomadic and seminomadic groups such as the Kazaks, Kalmyks, and Mongols. The largest of these polities was the Dzungar Khanate, existing from 1635 to 1757: in the early eighteenth century, it was still capable of challenging both Russia and China. This period and this region saw a rapidly changing power balance with global repercussions. Despite its importance, however, this region has still not become fully integrated into debates of early modern globalisation. Brigitta, in the midst of this shift, offers a perfect opportunity to tie together conflicts and developments that are synchronous but too seldom understood as interconnected.

Over the last decades, global history has helped bring back macro narratives and overarching argument to the field of history. In the early 2000s, warning flags were raised about the risk of presenting the globalisation process as too smooth. This criticism led to a constructive debate about the potential bias on mobility and certain regions, and about global history's dearth of studies of gender and social relations, and its lack of attention to asymmetric power relations. ${ }^{7}$ To resolve these issues, it follows naturally for global historians to turn to microhistory and biographical approaches for a counterbalance. After all, historians have done so before: from the 1970s and onwards, women's history used studies of a single or a small group of individuals to reveal and examine structures of power both in history and in our narratives. By paying minute attention to those considered unimportant, women's history and social history introduced new foci and disrupted faulty macro narratives. ${ }^{8}$ The benefit goes both ways: criticism against traditional microhistorical scholarship includes weak power analyses and an unwillingness to connect to large

\footnotetext{
${ }^{3}$ Andre Gunder Frank, 'The Centrality of Central Asia', Bulletin of Concerned Asian Scholars 24, no. 2 (1992): 84.

${ }^{4}$ Scott C. Levi, 'Early Modern Central Asia in World History', History Compass 10, no. 11 (2012): 866-78; the argument is elaborated in Scott C. Levi, The Bukharan Crisis: A Connected History of 18th Century Central Asia (Pittsburgh: University of Pittsburgh Press: 2020), 2-9; such studies include Eric Tagliacozzo, Helen F. Siu, and Peter C. Perdue, eds., Asia Inside Out: Connected Places (Cambridge, MA: Harvard University Press, 2015); Pamela Kyle Crossley, Helen F. Siu, and Donald S. Sutton, eds., Empire at the Margins: Culture, Ethnicity, and Frontier in Early Modern China (Berkeley: University of California Press, 2006).

${ }^{5}$ See Michael Khodarkovsky, Russia's Steppe Frontier: The Making of a Colonial Empire, 1500-1800 (Bloomington: Indiana University Press, 2002); Alexander V. Lukin, ed., Rossiia i Kitai: Chetyre veka vzaimodeistviia. Istoriia, sovremennoe sostoianie i perspektivy razvitiia rossiisko-kitaiskikh otnoshenii (Russia and China: Four Centuries of Interaction. History, present state and future prospects for the development of Russian-Chinese relations) (Moscow: Ves' Mir, 2013).

${ }^{6}$ China here refers to the region ruled by the Ming and then the Qing dynasty, despite the expansion of the latter.

${ }^{7}$ This debate goes back to Frederick Cooper, 'What Is the Concept of Globalization Good for? An African Historian's Perspective', African Affairs 100, no. 399 (2001); a recent addition is Jorge Cañizares-Esguerra, 'On Ignored Global "scientific Revolutions"', Journal of Early Modern History 21 (2017): 420-32.

${ }^{8}$ Lois W. Banner, 'Biography as History', The American Historical Review 114, no. 3 (2009): 579-86; Hans Renders and Binne De Haan, Theoretical Discussions of Biography: Approaches from History, Microhistory, and Life Writing (Leiden: Brill, 2014), 51.
} 
narratives that risks the reproduction of Eurocentrism. ${ }^{9}$ This tension between the seemingly linear story that follows from a focus on one life, and the will to disrupt large - even teleological - narratives lies at the very heart of biographical methodology, and makes the combination with global history so productive. ${ }^{10}$ Natalie Zemon Davis argued for the necessity of keeping history local, social, and concrete, while addressing questions of global history; global microhistorical studies have now for a decade done so in practice. ${ }^{11}$ The subjects of global microhistorical studies to date include traders, diplomats, missionaries, colonial clerks, explorers, and other people who aimed to be where they were (including a Chinese warlord and a Muslim trickster), but this approach has also brought attention to captives and slaves - a number of them female. ${ }^{12}$ Nevertheless, global history is still some way from integrating gender as a standard analytical lens, be it in the form of masculinity, femininity, gender roles, household economy, sexuality - or the mere presence of women. ${ }^{13}$

This article contributes with a story of an unfree woman. The prisoners of the Great Northern War have, by and large, been seen through a narrow lens in the Swedish historiography, with a focus either on their poor living conditions, or on their supposed economic and scientific contributions, rather than seeing these facts as intertwined. Russian scholars have taken the lead in placing these prisoners within a larger framework of imperial expansion. ${ }^{14}$ Brigitta, however, is presented either as an appendix to her husband, or as a curiosity. In that, Brigitta is typical for how a transregional life is framed - and diminished - as the fate of a 'strong woman'. ${ }^{15}$ This label of exceptionality is reminiscent of Walter Johnson's classic argument, according to which we foremost identify agency in slaves when they are subversive, making them even more invisible when they are not. ${ }^{16}$ In contrast, one can follow the lead of Joan Scott, and make use of a biography to rephrase the subject itself. ${ }^{17}$ Brigitta's story is not of a woman unlike any other, and it should be taken placed in a context of dramatic Eurasian change: she was not the only prisoner, but one of tens of thousands.

\footnotetext{
${ }^{9}$ Marta Araújo and Silvia Rodríguez Maeso, The Contours of Eurocentrism: Race, History, and Political Texts (Lanham: Lexington Books, 2015), 80; Heather L. Johnson, 'Narrating Entanglements: Rethinking the Local/Global Divide in Ethnographic Migration Research', International Political Sociology 10, no. 4 (2016): 383-97.

${ }^{10}$ See Francesca Trivellato, 'Is There a Future for Italian Microhistory in the Age of Global History?', California Italian Studies 2, no. 1 (2011).

${ }^{11}$ Natalie Zemon Davis, 'Decentering History: Local Stories and Cultural Crossings in a Global World', History and Theory 50, no. 2 (2011): 188-202.

${ }^{12}$ Influential examples include Tonio Andrade, 'A Chinese Farmer, Two African Boys, and a Warlord: Toward a Global Microhistory', Journal of World History 21, no. 4 (2010): 573-91; Natalie Zemon Davis, Trickster Travels: A Sixteenth-Century Muslim between Worlds (London: Faber \& Faber, 2006); John-Paul A. Ghobrial, 'The Secret Life of Elias of Babylon and the Uses of Global Microhistory', Past \& Present 222, no. 1 (2014): 51-93; and Linda Colley, 'The Narrative of Elizabeth Marsh: Barbary, Sex, and Power', in The Global Eighteenth Century, ed. Felicity A. Nussbaum (Baltimore: Johns Hopkins University Press, 2003).

${ }^{13}$ This was noted already in Patrick Manning, Navigating World History: Historians Create a Global Past (Gordonsville: Palgrave Macmillan, 2003), 201-10; still in Merry E. Wiesner-Hanks, 'Early Modern Gender and the Global Turn', in Mapping Gendered Routes and Spaces in the Early Modern World, ed. Merry E. Wiesner-Hanks (Farnham: Ashgate, 2015), 59-60; and still in Maria Sjöberg, 'Gender Meets World History: Family and Political Regency', Entremons: UPF Journal of World History, no. 8 (2016): 3-25.

${ }^{14}$ Alf Åberg and Göte Göransson, Karoliner (Carolingians) (Höganäs: Wiken, 1989); Lena Jonson and Tamara Alekseevna Torstendahl Salytjeva, Poltava: krigsfängar och kulturutbyte (Poltava: Prisoners of War and Cultural Exchange) (Stockholm: Atlantis, 2009); Galina Shebaldina, Shvedskie Voennoplennye v Sibiri: Pervaia Chetvert' XVIII Veka (Swedish Prisoners of War in Siberia: The First Quarter of the 18th Century) (Moscow: RGGU, 2005); Sergei A. Kozlov, Russkie plennye Velikoj Severnoj vojny. 1700-1721 (Russian Prisoners in the Great Northern War. 1700-1721) (St. Petersburg: Istoricheskaja illjustracija, 2011).

${ }^{15}$ This is even the title of a book including her story: Gunnar Jarring, 'Skånskan som blev kalmuckernas fånge' (the Scanian woman who became prisoner of the Kalmyks), in Starka kvinnor (Strong women) (Stockholm: Sveriges radio, 1986), 110-18.

${ }^{16}$ Walter Johnson, 'On Agency', Journal of Social History 37, no. 1 (2003): 113-24.

${ }^{17}$ Joan Wallach Scott, 'Gender: A Useful Category of Historical Analysis', The American Historical Review 91, no. 5 (December 1986): 1053-75.
} 
In addition to a stress on overland connections, the story of Brigitta can thus help expand debates on the actors of global history. For that expansion, her social status is as important as her sex. Richard Drayton and David Motadel recently argued that global history, rather than focusing on elite actors, has had a long engagement with forced migration, and an interest in subordinate groups. ${ }^{18}$ Indeed, the analytical strength of global microhistory lies not least in its potential to illuminate complex power relations and the diversity of actors whose web of connections brought the early modern world together. ${ }^{19}$ Here, global history can cross-pollinate other fields: the complexity of power relations revealed in research on slavery and other forms of coercion has shown the need for regional comparison, attention to connections, and for expanding the types of sites in which coercion is studied - and global microhistory is a way to do so. ${ }^{20}$

In this context, mobility is no marker of freedom, or even of choice. Mobility can nevertheless be a marker of connections. To use prisoners of war and slaves, such as Brigitta, helps shed light on ruptures in intercultural interactions - that is, the people, ideas and things that could not, or would not, move or connect. ${ }^{21}$ Here, I focus on those forced into entanglements. Global history might long have paid attention to marginal and coerced actors, but these actors need to be considered not just as 'globalisation's losers', as suffering the effects of large historical shifts, but also as potential motors of early modern globalisation.

Global microhistorical studies should not only work to illustrate the local and minute workings of already known large-scale processes, but also they should help change what we think we know. The global connections that will be traced here are classic ingredients in demonstrating connections of a global nature: Brigitta's story includes migration, interregional economic integration, cross-border trade, circulation of knowledge, the spread of literary depictions, and diplomatic encounters. What makes this story different is the region, Central Asia, and the unfree woman we follow there. The location and the actors of this case make it possible to further our narrative of early modern globalisation, and resolve some of the issues that remain after two decades of attention to connections and comparisons: globalisation was also driven by overland connections, and shaped by unfree women such as Brigitta.

\section{From Bäckaskog to Tobolsk}

The story starts at the estate of Bäckaskog in southern Sweden. There, Brigitta Scherzenfeldt was born in 1684 . The family was reasonably well off, the father was an officer, but left her an orphan as a young girl. When she was 15 , she had the bad fortune of marrying a low-ranking officer in the Swedish army called Mats Bernow. ${ }^{22}$ This was an unfortunate match not because he was an army man, but because it was 1699 and the Great Northern War was just about to start; it would continue to rage from 1700 to 1721 . The war was fought between, on the one side, a coalition between

\footnotetext{
${ }^{18}$ Richard Drayton and David Motadel, 'Discussion: The Futures of Global History', Journal of Global History 13, no. 1 (March 2018): 10.

${ }^{19}$ Examples include Desley Deacon, Penny Russell, and Angela Woollacott, Transnational Lives: Biographies of Global Modernity, 1700-Present (Basingstoke: Palgrave Macmillan, 2010); Miles Ogborn, Global Lives: Britain and the World, 1550-1800 (Cambridge: Cambridge University Press, 2008); Mark Gamsa, 'Biography and (Global) Microhistory', New Global Studies (2017), 231-41.

${ }^{20}$ Damian Alan Pargas, 'Slavery as a Global and Globalizing Phenomenon', Journal of Global Slavery 1, no. 1 (2016): 1-4; Christian G de Vito and Anne Gerritsen, 'Micro-Spatial Histories of Labour: Towards a New Global History', in Micro-Spatial Histories of Global Labour, ed. Christian G. de Vito and Anne Gerritsen (Cham: Palgrave Macmillan, 2018), 1-11.

${ }^{21}$ Robert N. Proctor, 'Agnotology: A Missing Term to Describe the Cultural Production of Ignorance (and Its Study)', in Agnotology: The Making and Unmaking of Ignorance, ed. Robert N. Proctor and Londa Schiebinger (Stanford: Stanford University Press, 2008), 1-36; Margot Finn, " Frictions " d'empire : les réseaux de circulation des successions et des patrimoines dans la Bombay coloniale des années 1780', Annales. Histoire, Sciences Sociales 65, no. 5 (2010): 1175-204.

${ }^{22}$ Brigita Scherzenfeldt, 'Personalier öfwer lieutnantens herr Johan Gustaf Renats maka, fru Brigitta Schersenfeldt' (Biography of Lieutenant Johan Gustaf Renat's wife, Mrs Brigitta Schersenfeldt), C.R. Berch's Collection, The Library of the Swedish Royal Academy of Letters, 3. His title is a 'förare', close to the rank of an ensign.
} 
Sweden, Holstein-Gottorp, and the Ottoman Empire: on the other was Saxony-Poland, Denmark-Norway, and Russia. As was usual at the time in most European armies, women followed the men to the front as part of what is today called the service corps, taking care of practicalities of army life. ${ }^{23}$ So Brigitta, like many wives, accompanied the army to the Russian front. ${ }^{24}$

Her marriage to Bernow was destined not to last long: only three years later, in 1703, her husband died at the battle of Thorn, in Poland. The news of his death found Brigitta in Riga, a Swedish Baltic possession. Her plans to make a life there was, in her words, 'a destiny that providence changed'. Instead, she remarried in 1704. When her new spouse, the sergeant Johan Lindström, was called to the front, she 'resolved to follow her beloved husband on the imminent march, and thereby show how in earnest she intended to love him in sickness and health'. ${ }^{25}$ They had six years together, during which they followed the Swedish army along the eastern front.

In 1709, the battle of Poltava constituted a catastrophic defeat for the Swedes. Both Brigitta and Johan Lindström were captured by the Russian army, together with 25,000 other men and women. ${ }^{26}$ Most were first taken as prisoners of war to Moscow, where Brigitta's second husband died in 1711. Not one to give up, Brigitta married another prisoner a year later. He was Michael Ziems, a lieutenant and one of many Germans working in this army. ${ }^{27}$ The Swedish army was mixed in terms of background, birthplace, and language.

To have a year in between the marriages was a conventional period of mourning, a 'widow's year' but, in a prison camp, to be an unmarried woman was to be unsafe. Much has been written on the influence of widows in the Swedish realm during this time, but the focus is on women at home, running the household. ${ }^{28}$ The few studies that mention Brigitta present her as a curiosity, a nearly unimaginable Swede. ${ }^{29}$ However, microhistory uncovers both the typical and the exceptional; it has the potential to reveal the norms as well as rule breakers who make clear where the lines are drawn. ${ }^{30}$ There is a deafening silence in the primary sources about Brigitta following her first husband to the front, the fact that she stayed there when he died, and her marriages - all of which shows the conventionality of these choices, and the reason to move beyond labelling her as exceptional.

The prisoners were initially held in camps close to Moscow and then moved on in groups. Most were sent as far away from the Eastern front as possible. The privates and petty officers were put to work for the Russians, for example in mines or in the shipyards, but working conditions were harsh, and the majority would not survive their captivity. Officers like Brigitta's husband Ziems were supposed to receive a small allowance from the Swedish war administration for prisoners of war in Moscow. Even for those who managed to stay in contact with this administration, the payments were small, erratic, and not enough to subsist on. ${ }^{31}$

Brigitta and her husband were taken to Tobolsk, the largest of the prison camps for Swedes. There, in close contact with the Russian local community, the prisoners found ways to make a living: they

\footnotetext{
${ }^{23}$ Maria Sjöberg, 'Stormaktstidens krig - och kvinnor: Något om betydelsen av perspektiv' (The Wars - and Women - of the Golden Age: on the Importance of Perspective), Historisk Tidskrift 127, no. 2 (2007): 203-23.

${ }^{24}$ Gunnar Thorvaldsen, 'Swedes in Siberian Diaspora', Sibirica 7, no. 2 (2008): 61; Alf Åberg, Fångars elände: karolinerna $i$ Ryssland 1700-1723 (The Misery of Prisoners: the Carolingians in Russia 1700-1723) (Stockholm: Natur och kultur, 1991$), 142$.

${ }^{25}$ Scherzenfeldt, 'Personalier', 3; this and all subsequent translations by the author.

${ }^{26}$ Åberg and Göransson, Karoliner, 131.

${ }^{27}$ Alf Åberg, Karolinska kvinnoöden (Carolingian Women's Fates) (Stockholm: Natur och kultur, 1999), 8.

${ }^{28}$ See Kekke Stadin, Stånd och genus i stormaktstidens Sverige (Estates and Gender in Sweden's Golden Age) (Lund: Nordic Academic Press, 2004), 85-90.

${ }^{29}$ Colibrine Sandström, Från Bäckaskog till Kalmuckernas Rike: [Brigitta Scherzenfeldts Liv](From Bäckaskog to the Realm of Kalmyks: [the Life of Brigitta Scherzenfeldt]) (Vejbystrand: Litteraturtjänst/Lindfors, 2005); Gunnar Jarring, 'Brigitta Scherzenfeldt och hennes fångenskap hos kalmuckerna' (Brigitta Scherzenfeldt and her Kalmyk Captivity), Karolinska förbundets årsbok (1983), 88-118.

${ }^{30}$ See Matti Peltonen, 'Clues, Margins, and Monads: The Micro-Macro Link in Historical Research', History and Theory 40, no. 3 (2001): 347-59.

${ }^{31}$ Åberg, Karolinska kvinnoöden, 9-18, 90.
} 
worked the fields, fished and hunted; they were active as masons, made and sold carvings, lace, embroideries and other craftwork. ${ }^{32}$ Despite rules prohibiting economic integration, this was a necessity not only for the prisoners, but also for the towns the camps were in; the Swedes made up almost $10 \%$ of the total population of Tobolsk. ${ }^{33}$ The importance of the camps goes beyond Tobolsk: Will Smiley argues that such eighteenth-century camps were at the centre for the development of modern prisoner-of-war system, though he focuses on the Russian-Ottoman frontier. ${ }^{34}$

Russian administrators consciously chose to recruit Swedish officers into service, because of their education, particularly in military technology and mapping - but also their availability. ${ }^{35}$ The prisoners were made part of Russian state building, and their influence is most often traced on an imperial level. In contrast, based on local Russian archives, Vasily Yuryev and Alexander Veshtomov argue that these camps contributed nothing to the local population. ${ }^{36}$ Galina Shebaldina, however, stresses the importance of the prison camps and the prisoners alike, and stresses how they helped enable the Russian expansion eastwards militarily and economically. ${ }^{37}$ The Swedish prisoners of war, alongside other captive groups, were key to the colonisation of Siberia, and help illuminate the inner workings of the Russian expansion. ${ }^{38}$ Albeit the camps underpinned Russian presence in the border region, the Swedes were no altruistic 'bringers of civilisation'. ${ }^{39}$ Their contributions were forced, and while Swedish officers were perceived as a resource, they were also expendable.

Coerced and unfree people, men and women alike, were no minority phenomenon in Siberia. The eastwards migration involved large numbers of Russian convicts, escaped serfs and exiles. Nearly, one-third of these were women. ${ }^{40}$ Andrew Gentes argues for the prevalence of convicting women to exile and purchasing local girls - even after the supposed abolition of slavery by Peter I. ${ }^{41}$ However, there were proportionally fewer women within the Swedish group. In the prisoners' diaries, there are both engagements and marriages (to say nothing of the extramarital affairs and illegitimate children) with local Russian women. ${ }^{42}$ This dearth might have affected Brigitta's marriage prospects: as the widow of an ensign, she had married 'down' when she wed a sergeant in Riga. In captivity in Moscow, she moved up in rank to a lieutenant.

\footnotetext{
${ }^{32}$ Leonhard Kagg, Leonhard Kaggs dagbok 1698-1722 (the Diary of Leonhard Kagg 1689-1722), ed. Adam Lewenhaupt (Stockholm: Nord. bokh., 1912), 222-7; Gunnar Jarring, 'Karolinerna i nyutkommen sovjetisk aktpublikation'(The Carolingians in Recent Publications of Soviet Records), Karolinska förbundets årsbok (1978), 24-49; Åberg, Karolinska kvinnoöden, 45.

${ }^{33}$ Åberg, Karolinska kvinnoöden, 38.

${ }^{34}$ Will Smiley, From Slaves to Prisoners of War: The Ottoman Empire, Russia, and International Law (Oxford: Oxford University Press, 2018), 105-24.

${ }^{35}$ Polnoe sobranie zakonov Rossijskoj imperii (Complete Collection of Laws of the Russian Empire), Tome 5, No. 3208, entry 11.06.1718.

${ }^{36}$ Vasily Yuryev and Alexander Veshtomov in Shebaldina, Shvedskie Voennoplennye $v$ Sibiri, 10.

${ }^{37}$ Shebaldina, 169, 174.

${ }^{38}$ Dariusz Kołodziejczyk, 'Captive Colonizers: The Role of the Prisoners of War from Poland Lithuania and the Crimean Khanate in the Russian Subjugation of Eastern Siberia', Journal of World History, forthcoming 2022.

${ }^{39}$ Though traditionally presented this way, see Ervin Petrovic Zinner, 'Ervin Petrovitj Zinner om de Karolinska krigsfångarnas insatser för utforskandet av Sibirien'(Ervin Petrovich Zinner on the Carolingian Prisoners of War's Contributions in the Exploration of Siberia), Karolinska förbundets årsbok (1979/1980), 48-119; this view is still present in Staffan Rosén, 'Conquerors of Knowledge: Swedish Prisoners of War in Siberia and Central Asia 1709-1734', in In Search of an Order: Mutual Representations in Sweden and Russia during the Early Age of Reason, ed. Ulla Birgegård and Irina Sandomirskaja (Huddinge: Södertörns Högskola: 2004), pp. 77-85.

${ }^{40}$ Estimate by Pëtr A. Slovtsov, Istoricheskoe obozrenie Sibiri. Stikhovoreniia. Propovedi (Siberian Historical Review. Poems. Sermons), ed. Viktor A. Kreshchik (Novosibirsk: Ven-mer, 1995), 219-20, see Peter Perdue, China Marches West: the Qing Conquest of Central Eurasia (Cambridge, MA: Belknap Press of Harvard University Press, 2005), 88-89.

${ }^{41}$ Andrew Gentes, "Licentious Girls" and Frontier Domesticators: Women and Siberian Exile from the Late 16th to the Early 19th Centuries', Sibirica: Journal of Siberian Studies 3, no. 1 (2003): 7; see David Collins, 'Sexual imbalance in frontier communities: Siberia and New France to 1760', Sibirica: Journal of Siberian Studies 4, no. 2 (2004): 162-85.

${ }^{42}$ Anders Pihlström, Anders Pihlströms Dagbok 1708-1723 (The Diary of Anders Pihlström 1708-1723) (Stockholm: Nord. bokh., 1903), 42, 82, 88 .
} 
Brigitta thus needed to navigate both an environment and a state of captivity precarious for women: in 1718, an emissary from Bukhara at the Russian court 'asked the tsar to give him a number of Swedish girls, or allow him to buy them'. This request was rejected, but the emissary 'did instead receive two Swedish whores, whom he carried away with him'. ${ }^{43}$ Not only was there a gender element to sending captives to Asia, but also unmarried women of low-social standing were more readily sent away than others. Gentes stresses that the exploitation of women's bodies and labour made them 'frontier domesticators', showing how the Russian central administration exiled women even for minor transgressions to improve the gender balance of the frontier communities, and turned a blind eye to the custom of purchasing local girls as brides for the male Russian colonisers. ${ }^{44}$

Attention to life in camp helps push global history beyond the mobility bias. It does so not by disregarding mobility, but by paying attention to its varied facets. In Tobolsk, the prisoners had the opportunity to take part in trade, but there was also a constant and forced movement between camps. ${ }^{45}$ For example, a Leonard Kagg noted in December 1712 how 'the lieutenant Michel Zims of Taub's dragoons with his wife', that is, Brigitta, were made to leave Tobolsk, only to return soon afterwards. ${ }^{46}$ Captivity was not a static condition. The Governor of Tobolsk hired Swedes as escorts when travelling around the land. Because Tobolsk was the capital of Siberia, most religious, scientific, trade, and diplomatic missions would pass through here. In 1712, Kagg notes the arrival of a Chinese embassy. ${ }^{47}$ The Swedish prisoner Johan Christoffer Schnitscher, who was at Tobolsk at the same time as Brigitta, escorted this embassy through Russia and to the khan of the Volga Kalmyks in Saratov. The Qing report of this journey influenced the view of Russia in the Qing Empire for decades; the travelogue by Schnitser from this same journey spread in Europe - and it was annotated by a Johan Renat, who had been a captive in Dzungaria with Brigitta. ${ }^{48}$ The prisoners demonstrate both voluntary and forced mobility and immobility with a vast regional reach and linguistic span.

Many prisoners joined the Russian army, either voluntarily or out of necessity. ${ }^{49}$ One of these was Brigitta's husband Ziems, who explained his decision with the fact that he was not a Swedish native. ${ }^{50}$ Ziems' decision would prove fateful: he was promoted to captain, and sent to the Dzungar border. This was a roundabout effect of the Great Northern War. In 1713, Tsar Peter I received a report that there was gold in Dzungaria. As the war with Sweden on the western frontier had proved long and expensive, he planned to fund it with gold from his eastern frontier. ${ }^{51}$ Numerous expeditions were dispatched: Kagg wrote in June 1715 that two regiments had left 'to conquer a stream with gold sand' but that 'the Russians were walloped by the Kalmyks'. ${ }^{52}$ In 1716, the Russians sent out an expedition with over 2,000 men, including Swedish mining engineers and artillery, one of whom was Ziems. ${ }^{53}$ Brigitta writes that 'as no hostilities from the other side were expected, the officers of the garrison had their wives brought to them', and she followed them. ${ }^{54}$ However, the Russian group was soon found and defeated by the Dzungars. Kagg writes that Ziems was killed, and that 'his wife was also taken prisoner, as was lieutenant Johan Debäsch

\footnotetext{
${ }^{43}$ Friedrich Christian Weber, Das veränderte Russland (Frankfurt, 1721), 254.

${ }^{44}$ Gentes, "Licentious Girls" and Frontier Domesticators', 5-7.

${ }^{45} \mathrm{Kagg}$, Leonhard Kaggs dagbok 1698-1722, 218-19.

${ }^{46}$ Kagg, 197.

${ }^{47}$ Kagg, 221-31.

${ }^{48}$ Johan Christian Schnitser, Berättelse, om ajuckiniska Calmuckiet (Account of Kalmykia under Ayuki) (Stockholm, 1744); Tulišen, Lakcaha jecen-de taküraha babe ejehe bithei/Man Han Yi yu lu jiao zhu (Annotated Records of foreign regions in Han and Manchu), ed. Zhuang Jifa (Taipei: Wen Shizhe Publishing House, 1983).

${ }^{49}$ Thorvaldsen, 'Swedes in Siberian Diaspora', 50.

${ }^{50}$ Scherzenfeldt, 'Personalier', 6.

${ }^{51}$ Perdue, China Marches West, 212.

${ }^{52} \mathrm{Kagg}$, Leonhard Kaggs dagbok 1698-1722, 227. Kagg uses 'Kalmyk' for various groups.

${ }^{53}$ Perdue, China Marches West, 212.

${ }^{54}$ Scherzenfeldt, 'Personalier', 7.
} 


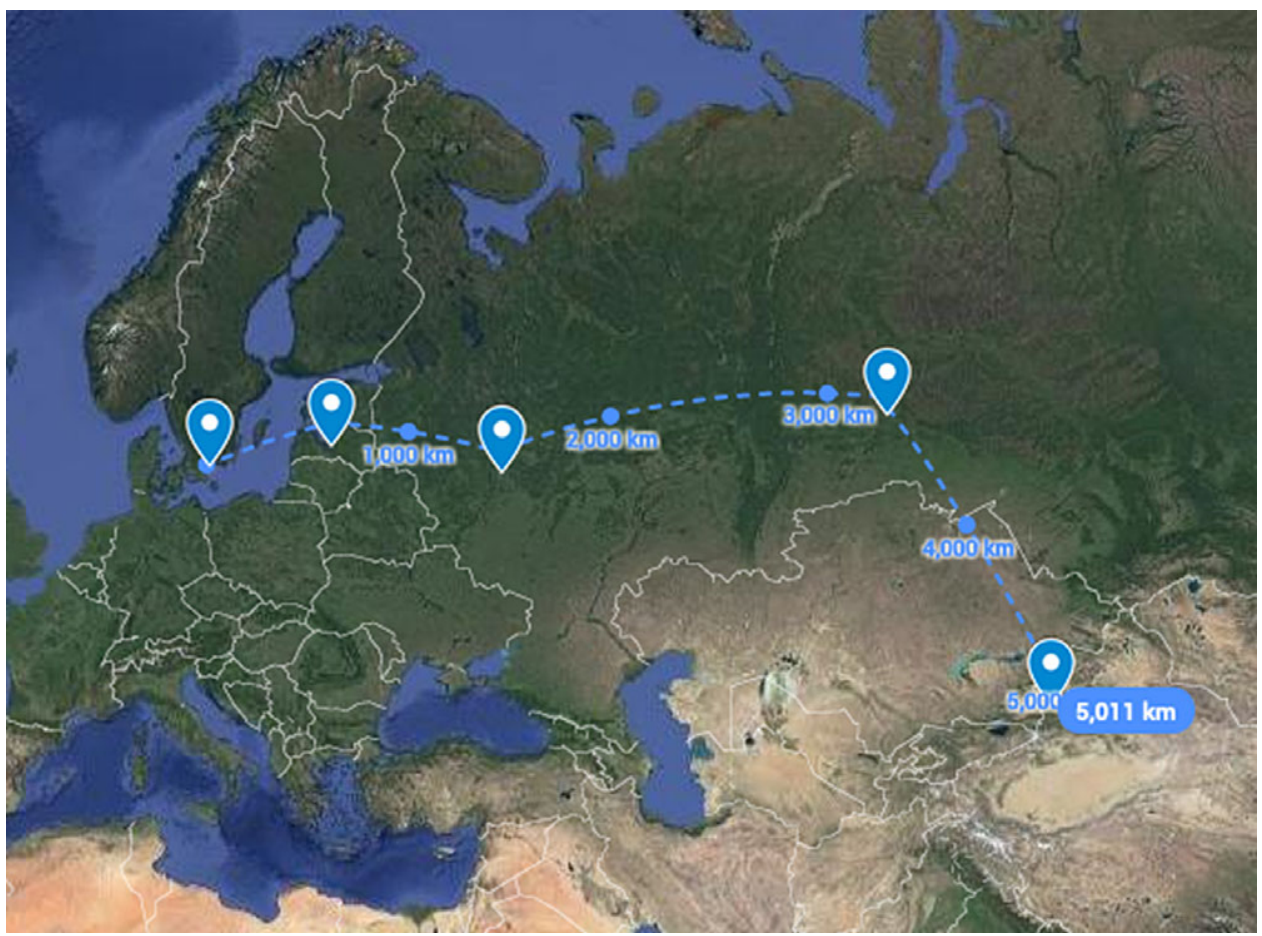

Figure 1. Map of Brigitta's journey (image based on Google Maps, 2020).

taken prisoner of the Kalmyks, as was our sergeant major Johan Renat'. ${ }^{55}$ Brigitta was thus captured a second time, and fell into what she called 'a hard and lamentable slavery'. ${ }^{56}$ She and the other prisoners would live in Dzungaria for years to come.

In the first decades of the eighteenth century, Brigitta Scherzenfeldt had thus travelled from Sweden to Thorn, to Narva, to Moscow, to Tobolsk, down the Irtysh river and would soon arrive in the Dzungar capital of Ghulja - 5,000 kilometres from where she started (see Figure 1).

It is both interesting how much Brigitta moved, and how little; her mobility depended on her sex, her status as prisoner, and her role as wife. It is clear that her room for manoeuvre was quite different from that of people who experienced other types of forced migration, such as from the large-scale forced migration in China during this era, from serfdom and from chattel slavery. ${ }^{57}$ When Jürgen Osterhammel warns us of the global history mobility bias, he stresses that not all people did move. ${ }^{58}$ Ada Ingrid Engebrigtsen takes a different tack, arguing that the bias in global history stems not from the fact that mobility is presented as ubiquitous, but that it is undertheorised. Mobility is not only a degree of movement and the manner in which a person moves, but also the reason for the movement and the story about it. ${ }^{59}$ Prisoners are particularly helpful to help further such discussions: they make clear the grey scale of coercion and, rather than establishing connections between mobility, autonomy, and freedom, they illuminate a geography of limitations. ${ }^{60}$ Global labour history

\footnotetext{
${ }^{55}$ Kagg, Leonhard Kaggs dagbok 1698-1722, 236.

${ }^{56}$ Scherzenfeldt, 'Personalier', 7.

${ }^{57}$ For a discussion of terms used for coercion in this region, see Alessandro Stanziani, Bondage: Labor and Rights in Eurasia from the Sixteenth to the Early Twentieth Centuries (New York: Berghahn, 2014), 63-88.

${ }^{58}$ Jürgen Osterhammel, 'Global History and Historical Sociology', in The Prospect of Global History, ed. James Belich et al. (Oxford: Oxford University Press, 2016), 38.

${ }^{59}$ Ada Ingrid Engebrigtsen, 'Key Figure of Mobility: The Nomad', Social Anthropology 25, no. 1 (2017): 42-54.

${ }^{60}$ See Dominique Moran, Carceral Geography: Spaces and Practices of Incarceration (Farnham: Ashgate, 2015), 1-7.
} 
underlines the importance of spatiality for understanding labour and incarceration, but the opposite also holds true: the conditions of labour impact spatiality. Brigitta's mobility cannot be understood through a concept such as freedom, or lack thereof, but becomes clearer if considered as an effect of her coerced labour. ${ }^{61}$ Although the part she played in interregional entanglements and as a motor of globalisation was not one of free choice, that does not equal passivity.

Prisoners of war in other contexts have been used to exemplify coerced migration, but the case of the Swedish prisoners constitutes an example of coerced migration of Europeans overland into Asia during the era of increased globalisation. In fact, as it ties together the Ottoman and the Russian Empires with North and West European powers on the one hand and the Russian and Qing expansions and their respective clashes with the Dzungar Empire on the other hand, the Great Northern War can and should be seen as an historical event with global implications.

\section{Life in Ghulja}

Taken captive anew, Brigitta was taken to Dzungaria. She was now 32 years old. The Dzungar Empire, at this time ruled by Tsewang Rabtan, was at its peak in terms of power and geographical reach. A semi-nomadic society, it stretched from Xinjiang to present-day Kazakhstan, and from present-day Kyrgyzstan to southern Siberia. There were several flows of coerced migration in this region, including prisoners of war landing in ransom slavery, or coerced labour. ${ }^{62}$ There is also a bodily aspect to this part of Brigitta's story. When her third husband was killed, she says that she was 'robbed of all her clothes, and chained so hard and long with iron and strong ropes, that she until her dying days bore marks of these shackles' ${ }^{63}$ Her very body was changed by the imprisonment.

Brigitta says that only upon arrival in Dzungaria was she 'given some old leather clothes, with which to cover her until then completely naked body'. ${ }^{64}$ At this time, the word 'naked' could mean dressed in nothing but a linen shift - a sexualised state of undress. ${ }^{65}$ Brigitta later told her story to a British noblewoman, Jane Vigor, who published a dramatized version as part of her letters from Russia. Vigor elaborated on the sexual element of Brigitta's hardship. In this version of the tale, one of Brigitta's captors 'liked her so well as to make love to her, and made the Russ his interpreter; but when intreaty [sic] would not prevail, he attempted force. She at last bit a piece of flesh off his bosom'. ${ }^{66}$ In Vigor's version, the ruler of the Dzungars gets involved in Brigitta's case and promises that 'no-body should force or molest her', making the heroine of the story a virtuous woman. Both versions engage with gendered friction in intercultural connections - not a disconnection or rupture, but unwilling connections wrought with conflict. Female prisoners traversed the steppe and took part in intercultural exchanges under threat of rape and unwanted sexual advances, and afterwards had to prove their virtue.

Brigitta became the possession of a well-to-do Dzungarian. In her autobiography, she says that she had to 'carry out hard and disgraceful tasks, such as are assigned to bonded serfs, and during this time make do with squalid, meagre and often filthy meals'. According to her, the Dzungar ruler demanded a tribute after successful raids, and as she was 'from a strange and in this land unknown nation', she was presented to the court. She was then 'gifted as a slave' to the ruler's Tibetan wife. ${ }^{67}$ Thus, Brigitta described herself as being unfree, suffering hardships, and in a faraway place, but also that her perceived exoticism was an advantage.

\footnotetext{
${ }^{61}$ Marcel van der Linden, 'Global Labor History: Promising Challenges', International Labor and Working-Class History 84 (2013): 218-25.

${ }^{62}$ Elena Smolarz, 'Unterwegs wider Willen. Mobilität in den Schilderungen russischer Sklaven im Buchara des 18. und 19. Jahrhunderts', Internationales Asienforum 45, no. 1-2 (2014): 85-111.

${ }^{63}$ Scherzenfeldt, 'Personalier', 8.

${ }^{64}$ Scherzenfeldt, 9.

${ }^{65}$ Lyndal Roper and Nancy Roper, Oedipus and the Devil: Witchcraft, Sexuality, and Religion in Early Modern Europe (New York: Routledge, 1994), 69.

${ }^{66}$ Mrs William Vigor, Letters from a Lady, Who Resided Some Years in Russia, to Her Friend in England (Pall-Mall, 1777$), 108$.

${ }^{67}$ Scherzenfeldt, 'Personalier', 8-9.
} 
In the years that followed, Brigitta built a life for herself at court - and puts this down to her own skills. She says that her 'crocheting and also her weaving made her more and more loved with her mistress'. According to Brigitta, her 'beautiful handicrafts' were so admired that the daughter of Tsewang Rabtan, 'the princess Seson', demanded Brigitta as a gift, 'as she in particular wished to learn how to crochet'. For the purpose of instructing her, Brigitta was moved to another part of the court, and 'found a particular favour'. ${ }^{6}$ Not only did she make her way in a foreign land, she did it using skills suitable to her sex and standing. Describing her upbringing, Brigitta stresses how she was raised 'to a god-fearing and virtuous life, and was taught such crafts as were proper for her sex and rank'. ${ }^{69}$ We might even compare Brigitta to Mary Rowlandson, a North American colonist who claimed to have used her knitting skills to survive Native American captivity in $1675 .^{70}$ These were abilities a woman could, indeed should, possess. When retelling Brigitta's tale, Jane Vigor picks up on the detail of Brigitta's needlework - in an earlier letter, Vigor had already mentioned her own. ${ }^{71}$ This can be seen as a story of a hands-on circulation of knowledge, if we include practical skills as part of that category. ${ }^{72}$ Textile production was a key industry in Central Asia, and one that both in economic history and the history of science has been used to demonstrate global connections. ${ }^{73}$

One of the reasons why Central Asia is not usually cited as a typical example for early modern globalisation is the perception that as maritime trade expanded, the Silk Road went into decline. However, Russian and Central Asian records on the commercial dynamics of this region show that Indo-Central Asian ties remained important; the trajectory of the overland trade with Russia simply shifted, from going through Iran to Astrakhan, to a more eastern trail traversing Bukhara - a route that took traders and merchants to the doorstep of Dzungaria. ${ }^{74}$ Including Central Asia does not only complement our view of early modern history, it changes it.

Brigitta had personal experience of this trade. In 1725, Seson was arranged to marry one of the grandsons of the ruler of the Volga Kalmyks; it was one of several attempts of the Kalmyks to form an alliance with the Dzungars to counteract the growing Russian influence. ${ }^{75}$ The Dzungars were closely linked to the Kalmyks and the Tibetans alike. Brigitta took part in the journey during which the precious goods for Seson's dowry were to be purchased, and states that 'for this purpose, I resided two years in Little Bukhara and the city of Yarkand'. ${ }^{76}$ The region she calls 'Little Bukhara' stretched from the Amu Darya river into the southern part of modern-day Xinjiang. Yarkand was the region's largest trading centre, famous for its arts and crafts. This journey was a major commercial event but, even as she took part in it, Brigitta still refers to herself as a slave; coercion and connections could go hand in hand.

This overland trade gradually changed: between the treaty of Nerchinsk in 1689 and the treaty of Kyakhta in 1727, Russia and China combined trade with their diplomatic missions. Russian

\footnotetext{
${ }^{68}$ Scherzenfeldt, $10-12$.

${ }^{69}$ Scherzenfeldt, 3.

${ }^{70}$ Mary White Rowlandson, The Narrative of the Captivity and Restoration of Mrs. Mary Rowlandson: New Reprinted in Facsimile (J. Wilson and son, 1903), 19.

${ }^{71}$ Vigor, Letters from a Lady, 87, 109.

${ }^{72}$ For the inclusion of practical knowledge, see Lissa Roberts and Simon Schaffer, 'Preface', in The Mindful Hand: Inquiry and Invention from the Late Renaissance to Early Industrialisation, ed. Lissa Roberts, Simon Schaffer, and Peter Dear (Amsterdam: Edita-The Publishing House of the Royal, 2007), xiii-xxvii.

${ }^{73}$ Notably, Giorgio Riello, Luca Molà, and Dagmar Schäfer, 'Introduction: Silk in the Pre-Modern World', in Threads of Global Desire, ed. Giorgio Riello, Luca Molà, and Dagmar Schäfer (Suffolk: Boydell \& Brewer, 2018), 1-18; see Janet Harvey, Traditional Textiles of Central Asia (New York: Thames and Hudson, 1997), 7-45.

${ }^{74}$ For arguments against decline, see Matthew Romaniello. 'Transregional Trade in Early Modern Eurasia', Oxford Research Encyclopedias (Published online October 26 2017); Levi, 'Early Modern Central Asia in World History', 870-2; Erika Monahan, The Merchants of Siberia: Trade in Early Modern Eurasia (Ithaca, NY: Cornell University Press, 2016), 33441; Levi, The Bukharan Crisis.

${ }^{75}$ Michael Khodarkovsky, Where Two Worlds Met: The Russian State and the Kalmyk Nomads, 1600-1771 (Ithaca, NY: Cornell University Press, 2006), 186.

${ }^{76}$ Scherzenfeldt, 'Personalier', 12.
} 
researchers point to the importance of these Russo-Chinese connections. Gradually, these increasingly sidelined the Dzungars both economically and politically. ${ }^{77}$ The first decades of the early eighteenth century constituted a time of economic integration of these lands. Studies of this caravan trade pay increasing attention to the Central Asian group of cultural, linguistic, and social brokers that enabled it - a group to which I would add the Swedes. ${ }^{78}$ The Swedish prisoners had become part of the local economy through a variety of mechanisms: through the prison camps in Russia as well as through ties with Central Asian caravan traders and Russian fur traders.

Brigitta's services to her new rulers provided her with 'a gradually more tolerable serfdom', but she claims that this favoured position 'was used for nothing else, than to try to gain more freedom for Christian slaves, mostly Swedes and Germans, who were held under severe conditions in private homes'. She enumerates a number of men who without her help could 'not even sate their hunger', among them a 'Mr Lieutenant Renat'. ${ }^{79}$ This was Johan Renat, a son of Jewish immigrants to Sweden from the Netherlands, who had converted to Christianity in 'the big Jewish baptism' of $1681 .{ }^{80}$ When she came back after two years in Yarkand, Brigitta claims that Johan had 'obtained complete freedom, and was particularly esteemed' at court - so much so that Tsewang Rabtan planned to send Johan as an 'ambassador' to the king of Sweden. ${ }^{81}$ Brigitta probably overstated both her and Johan's importance, but such plans were not completely unlikely for the Russian, Qing, and Dzungar Empires; the early eighteenth century was a time of frantic information gathering and trade, often in the form of diplomatic missions.

Swedish prisoners of war are found in these diplomatic exchanges because of their linguistic and scholarly skills, and their intermediary position, but equally relevant was their expendability. Their coercion made them suitable to use towards large-scale interpolity integration: in other words, for globalisation. Swedish prisoners were enlisted to accompany Russian missions to Beijing, a Chinese mission to the Mongols, and a Chinese mission through Russian territory to the Kazaks. ${ }^{82}$ Adherents of New Diplomatic History stress the role of nonconventional and nonofficial actors in interpolity relations. ${ }^{83}$ The Swedish prisoners offer an example when even coerced actors took part in diplomatic connections, and helped tie regions together.

One of the results of these connections was the circulation of knowledge: an excellent example for which is mapmaking. During this time, China, Russia, and Dzungaria all engaged in mapping endeavours as part of their imperial projects, just as European states did. This process should not be understood merely as an imported practice. ${ }^{84}$ Recent research stresses the importance of Central Asian informants, also in the cartographic exchanges between Russia and China. ${ }^{85}$

\footnotetext{
${ }^{77}$ Natalia Platonova, 'Le commerce des caravanes russes en Chine du XVIIe siècle à 1762', Histoire, économie \& société 30, no. 3 (2011): 3-27.

${ }^{78}$ See Takahiro Onuma, Shin to Chūōajia sōgen: Yūbokumin no sekai kara teikoku no henkyō e (The Qing and the Central Asian Steppe: From the World of Nomads to the Frontiers of Empire) (Tokyo: The University of Tokyo Press, 2014); see Monahan, The Merchants of Siberia.

${ }^{79}$ Scherzenfeldt, 'Personalier', 10-11.

${ }^{80}$ Åberg, Fångars elände, 157.

${ }^{81}$ Scherzenfeldt, 'Personalier', 12-13.

${ }^{82}$ Lorenz Lange, Tagebuch zwoer Reisen, welche in den Jahren 1727, 1728 und 1736 von Kjachta und Zuruchaitu durch die Mongoley nach Peking gethan worden (Leipzig, 1781); Schnitscher, Berättelse om ajuckiniska Calmuckiet; Tulišen, Man Han Yi yu lu jiao zhu.

${ }^{83}$ Christian Windler and Hillard von Thiessen, 'Einleitung: Außenbeziehungen in akteurszentrierter Perspektive', in Akteure der Aussenbeziehungen: Netzwerke und Interkulturalität im historischen Wandel, ed. Hillard von Thiessen and Christian Windler (Köln Weimar: Böhlau Verlag, 2010), 1-12.

${ }^{84}$ Cordell D. K. Yee, 'Traditional Chinese Cartography and the Myth of Westernization', in The History of Cartography, II:2, ed. Brian Harley and David Woodward (Chicago: University of Chicago Press, 1994), 170-202; Mario Cams, Companions in Geography (Leiden: Brill, 2017); Steven Seegel, Mapping Europe's Borderlands: Russian Cartography in the Age of Empire (Chicago: University of Chicago Press, 2012).

${ }^{85}$ Helena Jaskov, 'The Negotiated Geography of the Treaty of Nerchinsk (1689) and the Role of the Jesuits', Late Imperial China 40, no. 2 (2019): 45-88.
} 
Such imperial maps were based on information from people of vastly different statuses, including German travellers, Dzungar courtiers, Russian diplomats, Kalmyk traders, Han officials, Bukharan guides, Jesuit missionaries, Tibetan clergy, and Swedish prisoners. In the midst of this vortex, Johan eked out a living. His skills as a mapmaker makes him quite typical for a Swedish officer, who had to demonstrate knowledge of mapping, geography, and mathematics to advance. ${ }^{86}$ Johan owned a Chinese and a Dzungar map of the Dzungar territory and the surrounding area. He claimed to have gained the former in a raid against the Chinese, and to have received the latter from the Dzungar ruler himself. Both gift giving and conquest were typical ways in which maps changed hands. In a letter, Johan says that he had copied and transcribed sections of these maps, and would do the rest if he had time, suggesting that he was able to read the texts on them.$^{87}$ Based on these maps, he drew his own: one of the very first European maps of Central Asia. ${ }^{88}$ While Johan was originally sent out to chart Russia for Sweden, and then the Russian borderlands for Russia, he ended up mapping the Dzungar Empire.

Brigitta and Johan were not the only captives in the Dzungar Empire; Tsewang Rabtan used prisoners from Sweden, Russia, and other parts of Central and Inner Asia to consolidate the empire - a strategic use of coerced actors parallel to that of both the Russian and the Qing Empire. ${ }^{89}$ The captives came in significant numbers: Poles, Ukrainians, Russians, and other Slavs were seized on the southern frontiers and dispatched to Central Asian markets at Bukhara, Samarkand, Khiva, or in the Crimea. ${ }^{90}$ So-called cosmopolitan environments in Central Asia could still be rife with structures of domination, economic control, and violence. ${ }^{91}$ The treatment of such prisoners were regulated in the Oriat law, in which they were called 'foreign specialists'. ${ }^{92}$ Still, central Asian traditions did not always conflate slave status with a loss of social identity; enslaved artisans continued to pursue their trades. ${ }^{93}$ Members of various Asian and non-Asian groups acted as diplomatic, commercial, and scientific brokers between Russia, China, and Dzungaria, but not all of them did so voluntarily.

The majority of coerced labourers, however, were constituted of a Muslim group forcibly moved into a different part of the empire, and directed to farming the land ${ }^{94}$ Brigitta and her fellow captives were thus also part of a conscious strategy of the Dzungar Empire to adapt to surrounding sedentary polities; this time and place illuminate a shift in nomad mobility. The notion of 'mobility' in global history comes with a lot of historiographical baggage, and tends to exclude nomads - as if global mobility would only apply to those who were otherwise sedentary. ${ }^{95}$ Briefly considering Brigitta in relation to environmental history reminds us of the role nomad mobility still played in the entanglements of the eighteenth century. What is more, she helps illustrate the increase in agriculture

\footnotetext{
${ }^{86}$ Wilhelm Sjöstrand, Grunddragen av den militära undervisningens uppkomst- och utvecklingshistoria i Sverige till år 1792 (The Basic Features of the Origin and Development of Military Teaching in Sweden up to the Year 1792) (Tierp: Tierps tryck, 1941), 15-16, 84, 105-14.

${ }^{87 ،}$ Acta Bibliothequae Upsaliensis Ab Anno 1727 D. 6 Aprilis', A. 8, 1743, Uppsala University Library, 200.

${ }^{88}$ 'Kalmuckisk karta' (Kalmyk Map), Renat 2/Renat B, Koba, Renat, Uppsala University Library; 'Kalmuckisk karta över Dzungariet' (Kalmyk Map of Dzungaria), Renat 1/Renat A, Koba, Renat, Uppsala University Library; 'Carta af Songarski = Kalmuckit' (Map of Dzungarian Kalmykia), Koba, Renat, Uppsala University Library.

${ }^{89}$ Perdue, China Marches West, 328; Andrew Gentes, Exile to Siberia, 1590-1822. Corporeal Commodification and Administrative Systematization in Russia (Basingstone: Palgrave Macmillan, 2008), 86-89; for a long-term context, see Jeff Eden, Slavery and Empire in Central Asia (New York: Cambridge University Press, 2018).

${ }^{90}$ Richard Hellie, 'Migration in Early Modern Russia, 1480s-1780s', in Coerced and Free Migration: Global Perspectives, ed. David Eltis (Stanford: Stanford University Press, 2002), 307-10.

${ }^{91}$ See Michael R. Feener, Challenging Cosmopolitanism: Coercion, Mobility and Displacement in Islamic Asia (Edinburgh: Edinburgh University Press, 2018), 2-6.

${ }^{92}$ Roman J. Pochekaev, 'Rossiiskie puteshestvenniki o pravovykh otnosheniyakh v Dzhungarskom khanstve XVIII v'. (Russian Travellers on Legal Relations in the 18th-Century Dzungar Khanate), Oriental Studies 12, no. 1 (2019): 28-40.

${ }^{93}$ Pamela Kyle Crossley, 'Slavery in Early Modern China', in The Cambridge World History of Slavery, ed. David Eltis and Stanley Engerman (Cambridge: Cambridge University Press, 2011), 199-200.

${ }^{94}$ James Millward, Eurasian Crossroads: A History of Xinjiang (New York: Columbia University Press: 2007), 92-93.

${ }^{95}$ Conrad, What Is Global History?, 191.
} 
under Tsewang Rabtan, which was part of large-scale ecological shift of the early modern period that is, the increased tension between nomad and agriculturalist land use. ${ }^{96}$ This tension was partly an effect of the little ice age, extending well into the period of the Great Northern War and with global repercussions; it can even help explain the war that brought Brigitta to the front. ${ }^{97}$

For Brigitta herself, however, it was her relationships that drove her story. Not only did she stress how she resisted sexual advances during her years of captivity, her narrative is built around her four marriages. Brigitta strictly defines herself and Johan as married, despite having met far from the nearest church, Protestant or otherwise. ${ }^{98}$ For the prisoners, Lutheranism was key to make sense of life in the Russian camps, and converts were not allowed in Sweden. ${ }^{99}$ Although the letters of Jane Vigor state that the couple was married in Moscow, also that would have been too late to rhyme with the expectations on a virtuous Swede. ${ }^{100}$ It is not clear how their relationship was viewed in Ghulja. When arranging his journey to Sweden, Johan had been granted that all the Swedish captives in Dzungaria would be put into his hands - all except Brigitta. Only at a later point was Brigitta granted permission to join Johan's party. She decided to stay at court until they set off, but then Seson demanded that Brigitta should join her suite once Seson was married. Apparently, the freedom Brigitta had been granted was as fractional as her coercion had been. Only by her marriage with Johan, she writes, was she liberated from her service at court - just in the nick of time. ${ }^{101}$

Tsewang Rabtan died in 1727, and in the subsequent power struggle Brigitta's loyalty was called into question. According to her, only her innocence and Johan's influence could save her. ${ }^{102}$ Tsewang Rabtan was eventually succeeded by Galdan Tseren. Nominally, both Brigitta and Johan were no longer enslaved and, back in Sweden, the war with Russia had been over for years - most prisoners of war had returned from Russia in 1722. However, Johan and Brigitta stayed in Ghulja and appeared to have found favour with the new ruler - Brigitta claims that she was supported by the ruler's family when 'her purchased Russian serfs' complained about her. ${ }^{103}$ That Brigitta overstated her position at court as well as her hardships is typical for the genre of captivity narratives. External sources do, however, confirm her presence and activity within the Dzungar court. A Russian emissary, Colonel Ugrimov, was in Ghulja from 1731 to 1732 and reported that both Brigitta and Johan held high positions there. ${ }^{104}$

Most years during which Brigitta was in Dzungaria, the empire saw limited fighting with Russia and the Qing Empire. However, there were increased tensions under the Yongzheng emperor (r. 1722-35). In 1731, the Chinese attacked the Dzungar border and faced a crushing defeat. ${ }^{105}$ One of the men involved in this border conflict was Brigitta's husband. The Dzungar leader later requested Russian artillery masters and iron craftsmen but, in the beginning, he depended on

\footnotetext{
${ }^{96}$ Joseph Fletcher, 'The Mongols: Ecological and Social Perspectives', Harvard Journal of Asiatic Studies 46, no. 1 (1986): 11-50; Levi, The Bukharan Crisis, 101-102.

${ }^{97}$ For the little ice age and the Great Northern War, see Sven Lilja, 'Klimatet, döden och makten : 1690-talets klimatkris', in Leva vid Östersjöns kust: en antologi om naturförutsättningar och resursutnyttjande på båda sidor av Östersjön ca 800-1800, ed. Sven Lilja (Huddinge: Södertörns Högskola, 2008), 23-79; for earlier impact, see Geoffrey Parker, Global Crisis: War, Climate Change, \& Catastrophe in the Seventeenth Century (New Haven: Yale University Press, 2011), 26-31.

${ }^{98}$ Scherzenfeldt, 'Personalier', 14.

${ }^{99}$ Elena Glavatskaya and Gunnar Thorvaldsen, 'Sibirskii Vavilon: Shvedskie uzniki v nachale XVIII v'. (Siberian Babylon: Swedish Prisoners at the Beginning of the 18th century), Quaestio Rossica, no. 4 (2015): 217.

${ }^{100}$ Vigor, Letters from a Lady, 110.

${ }^{101}$ Scherzenfeldt, 'Personalier', 13-14.

${ }^{102}$ Scherzenfeldt, 14.

${ }^{103}$ Scherzenfeldt, 16.

${ }^{104}$ Vladimir S. Miasnikov, ed., Russko-kitaiskie otnosheniia v XVIII veke. Dokumenty i materialy. 1729-1733. Vol V (Russian-Chinese Relations in the 18th century. Documents and Materials. 1729-1733) (Moscow: Pamjatniki istoricheskoe mysli, 2016), 509.

${ }^{105}$ Perdue, China Marches West, 239, 250, 254.
} 
prisoners to support this industry. ${ }^{106}$ Johan later claimed to have built artillery in Dzungaria and, according to the diaries of Ugrimov, Johan helped cast fifteen 4-pounders, five 'small cannons' and twenty 10-pounders for the army of the new Dzungar ruler, Galdan Tseren. ${ }^{107}$ A Russian captive, Ivan Sorokin of Kuznetsk, wrote that Johan was assigned a hundred Russians to transport iron ore for this project. Both Johan and Ugrimov mention the former's battles against the Chinese: Johan notes a raid in Turpan, and Ugrimov a battle at the city of Lükchün. ${ }^{108}$ Again, the presence of Swedish prisoners of war on several sides of the Dzungar-Russian-Chinese border conflict is less a sign of their flexibility than of their dispensability. Their presence does, however, help show how many groups were part of the world-changing Russian-Chinese contacts in Central Asia. ${ }^{109}$

Rather than construing Brigitta as exceptional, she should be viewed as part of a larger story. She and Johan illuminate how European and Asian military, economic, diplomatic, and scholarly ties depended on go-betweens, some of which were prisoners of war. Brigitta's journey from Ghulja to Yarkand, and back again, exemplifies the degree to which she was allowed to, was in fact made to, travel and trade. This trade, as much as scholarly and diplomatic exchanges, helped construct a chain of contacts spanning the vast distance from Beijing to St. Petersburg, and down to Lhasa.

\section{Moscow, again}

In 1732, Brigitta Scherzenfeldt and Johan Renat were granted permission to leave Ghulja. It is not clear whether this was a result of changes within the court, of Johan's position, or simply because they were no longer useful. When Colonel Ugrimov ended his mission to the court and returned to Russia in 1733, Brigitta and Johan accompanied him. ${ }^{110}$ They were not the only ones making the trip. In the words of Brigitta, at this point ' 18 Swedish and 134 Russian souls were delivered from slavery'. ${ }^{111}$ Once in Russia, Brigitta and Johan had to walk the tightrope of assuring the Russians of their loyalty to them, despite the fact that it had been their good relationship with the Dzungar ruler, which had allowed them to leave Ghulja. In Moscow, Johan was imprisoned for treason, because he had helped the Dzungars in their fight against China, and made weaponry for use against Russia. Brigitta said that his helping the Dzungars with 'artillery, science and tactics' had 'awoken a great hatred' among the Russians. ${ }^{112}$ The entanglements with local societies that make the couple such a good example for global history, was for them a source of trouble.

The journey back to Sweden also meant new intercultural entanglements. In Moscow, Brigitta met the British Jane Vigor. The two probably communicated in German, as Vigor lamented her own poor Russian, and Brigitta would have spoken German to her third husband. ${ }^{113}$ Their language skills enabled these women to share experiences. When Vigor published Brigitta's story as the story of a 'Swedish captive lady', she framed it in relation to other sexualised captivity narratives, turning Brigitta story into a commercial narrative of lifelong virtue. ${ }^{114}$

\footnotetext{
${ }^{106}$ Vladimir G. Datsyshen and Nikolai S. Modorov, 'Russko-dzhungarskiie otnosheniia v 1717-1745' (Russian-Dzungarian Relations 1717-1745), Mir Evrazii 2, no. 2 (2008): 18.

${ }^{107}$ Letter from Johan Renat 23 August 1739, vol. 411, Renat, Johan Gustaf:1, the Archive of Gunnar Jarring, Lund University Library.

${ }^{108}$ Miasnikov, Russko-kitaiskie otnosheniia 1729-1733, 509, 838; Letter from Johan Renat 25 April 1743, Brev till o från Andr. Norrenius g. 190, Uppsala University Library.

${ }^{109}$ Perdue, China Marches West, 523; see Jaskov, 'The Negotiated Geography of the Treaty of Nerchinsk'.

${ }^{110}$ Miasnikov, Russko-kitaiskie otnosheniia 1729-1733, 579.

${ }^{111}$ Scherzenfeldt, 'Personalier', 17.

${ }^{112}$ Scherzenfeldt, 20.

${ }^{113}$ Vigor, Letters from a Lady, 19, 88.

${ }^{114}$ Vigor, Letters from a Lady, 107-110; c.f. Leo Loewenson, 'Lady Rondeau's Letters from Russia (1728-1739)', The Slavonic and East European Review 35, no. 85 (1957): 399-408; Annette Kolodny, 'Among the Indians: The Uses of Captivity', Women's Studies Quarterly 21, no. 3/4 (1993): 184-95.
} 
When the couple arrived at St. Petersburg, it was Johan who was invited to share his experiences: he met the French mapmaker and astronomer Joseph-Nicolas Delisle and showed his Chinese map. Delisle promised Johan a printed version, but this never materialised. Laconically, Johan states that 'therefore, I think [my map] has been copied in Russia'. ${ }^{115}$ This places Johan in a network of cartographers in contact with the Jesuits in Beijing, such as Antoine Gaubil. Details from Delisle's maps can be found in later maps of the Chinese mapmaker Li Mingche; mapmakers such as Jean-Baptiste Bourguignon d'Anville would in turn rely on Chinese maps. ${ }^{116}$

Johan was equally immersed in Russian scholarly circles. In May 1734, he met the president of the St Petersburg Academy of Sciences and the sinologist Theophilus Bayer. ${ }^{117}$ Bayer had ties not only to Jesuits in Beijing and to French cartographers, but also to the Swedish bishop and scholar Eric Benzelius in Linköping. Benzelius and Bayer discussed Johan's map, and compared it to Chinese and Japanese specimens. ${ }^{118}$ Bayer says that he showed a Buddhist painting, a thangka (which he probably received from Henrik Johan Rehbinder, another Swedish prisoner), to 'a Swede who had lived nineteen years amongst the Kalmyks'. ${ }^{119}$ Bayer referred to Johan as an expert on the politics of Dzungaria, the Kalmyk script, and Buddhist iconography. ${ }^{120}$ Tibetan Buddhism was a crucial cultural element for the Dzungars, and legitimised Tsewang Rabtan's rule: it is very likely Johan had been immersed in expressions of the faith, and here helped spread that knowledge to Russia and beyond. ${ }^{121}$

This circulation of knowledge about Central Asia took place all over Eurasia: maps were sent to and from Beijing and Nagasaki, through St. Petersburg and Linköping down to Paris. These intercultural connections, in particular those making use of the religious networks in China, were in place well before the eighteenth century. ${ }^{122}$ Both the history of science and global history still suffer from an Anglophone conception of the world, in which certain regions are given disproportional attention but, if we look beyond the most widely studied works, the great diversity of knowledge comes to the fore. ${ }^{123}$ For this reason, we should pay particular attention to Central Asia. Matthew Mosca argues that the development of maps in Central Asia can be read as a sign of interlocking intellectual currents and common research trends in early modern Eurasia; David Mervart even suggests the existence of a premodern 'Eurasian republic of letters'. ${ }^{124}$ In short, the circulation of knowledge was not a mere effect of globalisation, but part of its machinery. The groups involved in this process were as diverse as their knowledge - and included coerced actors.

\footnotetext{
${ }^{115}$ Letter from Johan Renat 25 April 1743.

${ }^{116}$ For Delisle and statecraft, see Christine Marie Petto, When France Was King of Cartography: The Patronage and Production of Maps in Early Modern France (Lanham, Md: Lexington Books, 2007), 93-4; Cams, Companions in Geography, 208-9.

${ }^{117}$ Theophilus S. Bayer, 'Fasciculus Manuscriptorum Orientalium', MS Hunter 211 (U.2.2), Bayer Collection, Glasgow University Archive, 74-5.

${ }^{118}$ Theophilus S. Bayer, 'Letter to Eric Benzelius', 1735, The archive of Eric Benzelius (E005/Br 10), Volume 14, Letter 100, Linköping City Archive; Theophilus S. Bayer, 'Notes on Chinese and Japanese Maps', MS Hunter Archive, Bayer Collection, B/ D3, Glasgow University Archive; see also Antoine Gaubil, 'Letter to T.S. Bayer', 17 July 1734, MS Hunter Archive, Bayer Collection, B/A4, Glasgow University Archive.

${ }^{119}$ Theophilus S. Bayer, 'Idolum Tangutanum, Sinicum, Mungalicum, Calmucicum, Japanicum, Ex Septem Palatiis Direptum, Simul Cum Variis Variarum Gentium et Nominibus et Interpretationibus', Ms Hunter 246 (U.4.4), Bayer Collection, Glasgow University Archive.

${ }^{120}$ Bayer, 'Fasciculus Manuscriptorum Orientalium', 54-65; Bayer, 'Idolum Tangutanum ... ', 8-12.

${ }^{121}$ Perdue, China Marches West, 148-9.

${ }^{122}$ Dominic Sachsenmaier, Global Entanglements of a Man Who Never Traveled: A Seventeenth-Century Chinese Christian and His Conflicted Worlds (New York: Columbia University Press, 2018), 22-43.

${ }^{123}$ Cañizares-Esguerra, 'On Ignored Global "scientific Revolutions"', 420-32; Charlotta Forss., The Old, the New and the Unknown: The Continents and the Making of Geographical Knowledge in Seventeenth-Century Sweden (Turku: Iloinen tiede, 2018), 246-52.

${ }^{124}$ Matthew W. Mosca, 'The Qing Empire in the Fabric of Global History' in The Prospect of Global History, ed. James Belich et al. (Oxford: Oxford University Press, 2016), 122; David Mervart, 'Is One Book World Not Enough?: The Eurasian Republic of Letters before the Nineteenth Century', Global Intellectual History 3, no. 2 (19 June 2018): 1-16.
} 


\section{Arriving in Stockholm}

Johan and Brigitta returned to Sweden in July 1734, after more than three decades abroad. There, they stressed their loyalty to the Swedish crown. Brigitta claims that Johan was only released from his imprisonment in Moscow through ties to the Swedish king. ${ }^{25}$ Similarly, they justified their activities in Russia: in the story told to Vigor, when attacked by Dzungar forces, 'the prisoners joined with their guards to prevent a second captivity'. ${ }^{126}$ Several prisoners of war wrote narratives to demonstrate their loyalty or to present themselves as scholars. ${ }^{127}$ Some accounts spread widely, others - such as Brigitta's and Johan's - only exist as manuscript and letters. Nevertheless, the accounts were made to be read: they overstate Johan's influence and underline Brigitta's limited freedom of choice. In his application to resign from active service, Johan refers to his 'stay' in Dzungaria. Brigitta, by contrast, uses the terms 'imprisonment', 'serfdom', and 'slavery'. ${ }^{128}$

Back in Sweden, Johan cooperated with other prisoners writing about the Central Asian borderlands. ${ }^{129}$ However, Johan was not a conscientious correspondent; in 1735, Bayer complained about not having received any replies from him. Bayer's correspondent Benzelius replied, 'It might not be unsuitable to turn to his wife instead, whose memory is better. ${ }^{130}$ Brigitta thus took an active part in the circulation of knowledge and stories from their time in Dzungaria.

Returning home, prisoners of war had to demonstrate their unbroken Protestant faith. Brigitta consistently stresses her faith, and depicts her struggles as a trial of God. Many prisoners referred to the time in Russia as their 'Babylonian captivity. ${ }^{131}$ Brigitta claims that she gave up her position in Ghulja because of her longing for the Swedish church. Another way of proving her faith was by converting others, and Brigitta brought home slaves of her own for this purpose. She started out from Ghulja with a group of twenty, but most either died on the way or were 'taken by the Russians to be converted into Orthodoxy'. Only three made it to Stockholm. ${ }^{132}$ In December 1735, Altan, Jamankiz, and Zara, aged 32, 20, and 16, respectively, were baptized as Anna Catarina, Maria Stina, and Sara Greta. Nothing is known about their lives after this point, and Brigitta herself died a few months later. ${ }^{133}$ This conversion was not a singular occurrence: in the village of Gråmanstorp in 1736, the former dragoon Mathias Brandt wanted to have his wife baptised. When questioned by the vicar, it turned out that she had come with him two years earlier when he had returned after 'nineteen years of serfdom under the Kalmyks'. ${ }^{134}$

The couple also brought home objects, with their own trajectories of power. Several Swedish prisoners presented gifts to learned institutions, but Johan took his time to do so. Long after Brigitta's death and only a short time before his own in 1743, he made a bequest to the library of Uppsala University. Among the objects were Dzungar knives, bowls, a Chinese numerical table ${ }^{135}$ and court clothes wrought in silk. ${ }^{136}$ One of these was Brigitta's own costume (see Figure 2). The bequest included his map of the Dzungar Empire, as well as his Qing and Dzungar maps. Johan explains that he was unable to finish his transcription, 'on account of the darkness of my eyes'. ${ }^{137}$

\footnotetext{
${ }^{125}$ Scherzenfeldt, 'Personalier', 21.

${ }^{126}$ Vigor, Letters from a Lady, 108.

${ }^{127}$ Linda Colley, Captives: Britain, Empire and the World 1600-1850 (London: Jonathan Cape, 2002), 13-15, 75.

${ }^{128}$ Letter from Johan Renat 23 August 1739.

${ }^{129}$ Schnitser, Berättelse om ajuckiniska Calmuckiet, se comments by Renat.

${ }^{130}$ Bayer, 'Letter from Bayer to Benzelius 1735 '.

${ }^{131}$ See for example Scherzenfeldt, 'Personalier', 21; c.f. Glavatskaya and Thorvaldsen, 'Sibirskiy Vavilon', 228.

${ }^{132}$ Scherzenfeldt, 'Personalier', 21-2.

${ }^{133}$ Jarring, 'Skånskan som blev kalmuckernas fånge', 117.

${ }^{134}$ Consistorii Ecclesiastici Protokoll, §. 2', 30 September 1736, vol. AI:13, the Archive of Lund Cathedral Chapter.

${ }^{135}$ 'Acta Bibliothequae Upsaliensis Ab Anno 1727 D. 6 Aprilis', 207-8.

${ }^{136}$ See Catherine Jami, The Emperor's New Mathematics: Western Learning and Imperial Authority During the Kangxi Reign (1662-1722) (Oxford: Oxford University Press, 2011), 192.

${ }^{137}$ Letter from Johan Renat 25 April 1743.
} 


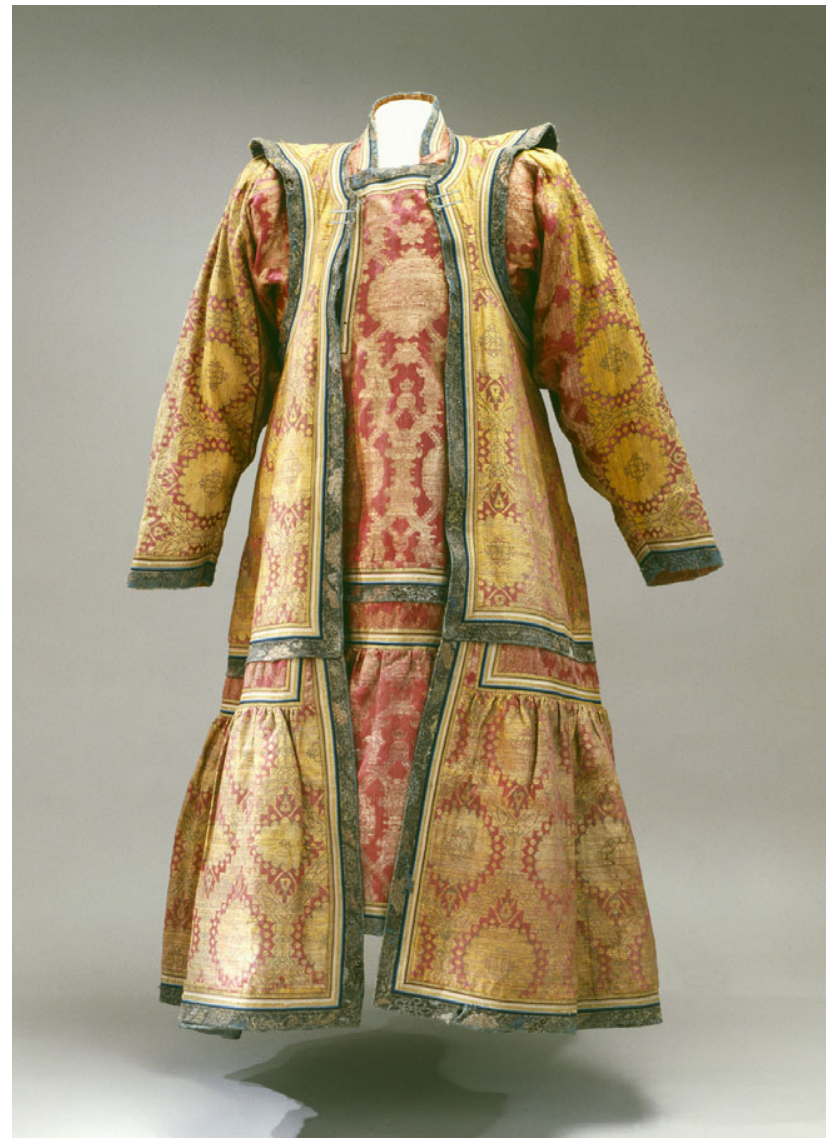

Figure 2. Brigitta's court costume (photo: Livrustkammaren/SHM).

Spoils of war such as Johan's Qing map are excellent examples of objects that reveal transcultural power relations; the Dzungar spoils of war from the Qing which were taken to Sweden were unusual. The receiving antiquarian noted, 'The bequest by this captain must be held for among the most precious that the library owns, and is therefore put in the oak chest, in which the Codex Argenteus is kept'. ${ }^{38}$ The Codex Argenteus remains the most prized object in the university's collections. Johan's bequest faced a different destiny. Brigitta's costume was worn by university janitors on formal occasions, before it was turned over to the royal armoury, whereas Johan's maps fell into obscurity and were rediscovered only in the early twentieth century in the course of a literary feud. ${ }^{139}$ The objects from Dzungaria were for a long time considered a marginal part of history, but that was not their initial reception; at the time of the bequest, the Dzungar Empire was still a powerful entity.

First in the mid-eighteenth century, the Dzungar Khanate lost its position as a powerhouse of Central Asia. In 1757, Qing forces exterminated the leading tribe of Dzungaria; some of the

\footnotetext{
138`Acta Bibliothequae Upsaliensis Ab Anno 1727 D. 6 Aprilis', 200.

${ }^{139}$ Åberg, Fångars elände, 158; Sigvard Reuterskiöld, 'Fakta rörande en dräkt från Centralasien förvarad å NordM' (Facts concering a costume from Central Asia stored at the Nordic Museum), (ms), EIa;2, Livrustkammaren, Stockholm; Patrick Hall, "Krig mot allt och alla": Strindbergs-fejden som politisk offentlighet' (“War against Everything and Everyone”: The Strindberg Feud as Polticial Public'), Scandia 70, no. 1 (2008): 30.
} 
conquered territory became 'the new border', Xinjiang, and the last nomad empire was gone. This violent respatialisation was understood in various ways. Ron Sela argues that, to come to terms with the state of decline, Central Asian historical literature stressed stories of past grandeur. ${ }^{140}$ In contrast, when the Russian and Qing Empire reconceptualised the region, the Dzungar khanate was erased and near-forgotten. ${ }^{141}$ As a comparison, Central Asia almost disappeared from the geographical imagination during the Soviet era. This conscious forgetfulness has been termed a 'cartographical dismemberment' - but it was not the first. ${ }^{142}$ Eighteenth-century Central Asia was in the midst of a dramatic conceptual and political shift. Stories from the Swedish prisoners of war that circulated in Europe and Asia helped create ideas about this space; at the same time, they were the result of the situation the prisoners found themselves in. To pay attention to them today helps us to undo later erasures and to see the role of Central Asia with early eighteenth-century eyes.

\section{Conclusion}

The life of Brigitta, with its regional spread and connection to economic, imperial and diplomatic developments, serves as a reminder to include both overland contacts and Central Asia as an arena in analyses of early modern globalisation. It also argues that coerced actors could be driving forces in that process. Indeed, global microhistories are not creating ruptures within the field of global history - they are actively helping to resolve its tensions. Global historians have, by and large, acknowledged that microhistorical studies support the scaling of our analyses between local and global levels, help us see the complexity in past power relations, and adjust which actors we put centre stage. Microhistorical studies such as this thus help us move from a single, straight trajectory to following the winding - but lived - roads such as the one that led from Ghulja to Stockholm.

Within global history, some scholars find it crucial to distinguish between 'mere events and fateful events, sequences leading to path dependent outcomes, and structure-modifying acts', as Jan de Vries has put it. ${ }^{143}$ Jeremy Adelman in contrast stresses that we should endeavour to 'include the parts and places of the world that have gotten disconnected and forgotten'. ${ }^{144}$ As I see it, there is no contradiction between the two. Both the Dzungars and female prisoners like Brigitta are examples of forgotten stories, but the events they illuminate were fateful for at least four empires.

To make sense of what Brigitta's story contributes to global history, we need not go further than the classics of global history. Sebastian Conrad counts five modes of integration, five motors of change, within global history. All can be clearly found in this case: communication (in the form of letter exchanges as well as face-to-face meetings), imperial and military expansion (by four different empires, if we include the final hurrah of the Swedish Baltic realm), shared institutions (the development of the prisoner of war system and the development of common forms of diplomatic exchanges), scientific and technical developments (such as mapping and cannon casting), and finally ecological changes (such as the conflict between nomadic and settled land use). ${ }^{145}$ Similarly, when Sanjay Subrahmanyam introduced the term 'connection' back in 1997, he wanted to show the limitations of comparative and modernisation history for exploring the very issues

\footnotetext{
${ }^{140}$ Ron Sela, The Legendary Biographies of Tamerlane: Islam and Heroic Apocrypha in Central Asia (Cambridge: Cambridge University Press, 2011), 117-40.

${ }^{141}$ Pamela Kyle Crossley, 'The Historical Writing of the Qing Imperial Expansion', in The Oxford History of Historical Writing: Volume 3: 1400-1800, ed. José Rabasa et al. (Oxford: Oxford University Press, 2012), 51-7.

${ }^{142}$ Martin W. Lewis and Kären Wigen, The Myth of Continents: A Critique of Metageography (Berkeley: University of California Press, 1997), 177-8.

${ }^{143}$ Jan de Vries, 'The Return from the Return to Narrative' (Max Weber Lecture, January 2013); for the 'causative power', see Jürgen Osterhammel, 'Global History and Historical Sociology', 34.

${ }^{144}$ Jeremy Adelman in Drayton and Motadel, 'Discussion', 19.

${ }^{145}$ Sebastian Conrad, What Is Global History? (Princeton: Princeton University Press, 2016), 103-7.
} 
discussed in this article: the spectrum from local to global, multiple actors, trade, military expansion, as well as the overseas and overland exchange of ideas in early modern Eurasia. ${ }^{146}$ We need to be careful not to stretch his concept to the point where it loses meaning. Not all history is connected, but this is - in its original sense.

Global history as a field has been justly criticised for its lack of gender analyses. Biographies and microhistory can help provide a balance. It would benefit global history to include not only female as well as male actors, but also to consider what femininity and masculinity meant to them, in practice and in theory. It was of key importance to Brigitta to show that she had kept her sexual and religious virtue, and lay claim to certain types of skills. Her husband Johan had had particular opportunities for education in mathematics and mapping, and presents his captivity differently. Analyses of gender naturally lead to an updated theorisation of space and movement itself: feminist geographers have long been concerned with how mobility and immobility is and has been gendered in discursive, political, and practical terms. ${ }^{147}$ Being more careful about stressing the power inherent in movement, forced movement, and immobility, allows us to explain the impact and presence of coerced actors: the life of Brigitta reveals asymmetric power relations at every turn, but she acted within a scale of coercion, and her activities were varied, mobile, and intercultural. Thereby, her case stresses friction in entanglements, and nuances notions of mobility. Such unwilling entanglements are particularly well mirrored in microstudies of individual lives. As Conrad stresses, globalisation is not a given or natural process, but was driven by actors. ${ }^{148}$ In this case, it was spurred on by a Swedish woman crocheting in captivity.

To see eighteenth-century Central Asia as a geopolitical and cultural crossroads helps us remember the multiplicity of past power relations, and consider times when non-European polities were expansive empires. Global history will be better for remembering the role played by overland connections for regional integration in the early modern era, as well as the power dynamics of gender and coercion of that integration. This argument relies on discussions within fields such as New Qing History, Russian Imperial history, and Central Asian studies, but it is the global approach that brings these insights to an aggregated level. ${ }^{149}$ Matthew Mosca, for one, proposes that Qing inland struggles changed the eighteenth-century world and should be seen as a global story. ${ }^{150}$ There lies no difficulty in integrating the centrality of overland connections, and the role of coerced and female actors, into the history of globalisation: they are already there. Brigitta brings this point home from the ground level and up.

During her decade in Russia and two decades in Dzungaria, Brigitta saw the world change: Russia expanded into the eastern steppe, and both the Qing and the Russian Empires clashed with a still significant Dzungar Empire. What is more, Brigitta exemplifies that intercultural entanglements in the realms of trade, diplomacy, migration, and knowledge could be effects of coercion. Slaves and prisoners did not just experience, or suffer from, the effects of the early modern globalisation process - they took part in it. Through them, we can address issues of inequality, friction, and nonmobility without losing track of how, overseas and overland, the world was tied together.

\footnotetext{
${ }^{146}$ Sanjay Subrahmanyam, 'Connected Histories: Notes towards a Reconfiguration of Early Modern Eurasia', Modern Asian Studies 31, no. 3 (1997): 735-62.

${ }^{147}$ Doreen Massey, Space, Place and Gender (Oxford: Polity Press, 1994), 1-16.

${ }^{148}$ Conrad, What Is Global History?, 108.

${ }^{149}$ Scott Levi, The Bukharan Crisis; see Jin Noda, Ro-Shin teikoku to Kazafu hankoku (The Kazakh khanate : between the Russian and Qing empires) (Tokyo: Tokyo University Press, 2011); Evelyn S. Rawski, Early Modern China and Northeast Asia: Cross-Border Perspectives (Cambridge: Cambridge University Press, 2015).

${ }^{150}$ Matthew W. Mosca, 'The Qing Empire in the Fabric of Global History', 109-13.
} 
Lisa Hellman is an award-winning historian, and currently a leader for the research group 'Coerced Circulation of Knowledge' at the Bonn Center for Dependency and Slavery Studies, University of Bonn, as well as a Pro Futura Scientia XV fellow at the Swedish Collegium for Advanced Study. Having earned her PhD at Stockholm University, she has since worked at Freie Universität Berlin and The University of Tokyo. Her first book 'This house is not a home: European everyday life in Canton and Macao 1730-1830' came out in Brill's Global Social History series in 2018. Hellman combines sources and literature in a dozen languages to produce work in the intersection between the global, social, and maritime history of East and Central Asia, with a special focus on gender.

Cite this article: Hellman L. 2022. Enslaved in Dzungaria: what an eighteenth-century crocheting instructor can teach us about overland globalisation. Journal of Global History 17: 374-393, doi:10.1017/S1740022821000176 